\title{
Florida Real Estate License Aspirants, Students, and Candidates' Dropout: A Qualitative Analysis
}

\author{
Luca D'Ottone * \\ School of Continuing and Professional Development, Miami Dade College, 300 NE 2nd Avenue Room 2221, \\ Miami Fl, 33132, United States of America \\ * E-mail of the corresponding author: ldottone@mdc.edu
}

\begin{abstract}
Real Estate is an industry playing a vital role in Florida's economy, thus generating a substantial amount of interest in the general population. Obtaining a Florida Real Estate license it is not an easy task though. The object of the present investigation is to outline the local licensing process and discuss the different routes that lead aspirants to drop out from the licensing system without earning their personal objective. Despite the low pass rates at the state licensure exam it could be argued that non-academic factors may have even a more significant impact on the ultimate fate of Florida Real Estate license aspirants. Further research is needed to clarify the relative proportions of each separate dropout path because of the fragmentary nature of the information currently available.
\end{abstract}

Keywords: real estate, Florida applicants, drop rates, licensure, aspirants

DOI: $10.7176 / \mathrm{JEP} / 10-11-02$

Publication date: April $30^{\text {th }} 2019$

\section{Introduction}

Real Estate is an industry playing a vital role in Florida's economy. For example, it has estimated that Florida commercial Real Estate alone, ranks third in the Nation in terms of volume (Fuller, 2018). The evolution of the Florida Restate industry has been described in great detail by Cummings (2006), beginning with the discovery of this new territory called "Pascua de Florida" in 1513 by Ponce de Leon, passing through the Florida land boom and bust of the 1920s, and exploring the more modern trends at the beginning of the 2000s. The rapid increase of real estate prices in the 1920 s in Florida stemmed from a myriad of complex and delocalized roots including a general feeling of optimism for the future, after the American victory if WWI, the introduction of cars as a way of transportation, and the perspective of a soaring stock market (Broker \& Hanes, 2014). Florida, favored by the warm climate and by the international exposure, quickly became a hot tourist spot, hosting mainly wealthy Americans from the Northeast where Florida was portrayed as a tropical paradise.

Famous remain the highlighted billboard posted by developer Carl Fisher in Times Square (New York City) in 1920 stating “It's June in Miami". Fisher intention was to attract the attention of bankers and trader on a state that was far away from the City (Hill, n.d.). Originally, in fact, Florida was a hard to sell land, mainly characterized by swampland that allowed rich speculators from up North, such as Hamilton Disson, to purchase large tracts of land at bargain prices. The rapid increase of Florida real estate prices observed in the roaring twenties came to a sudden end when the New York stock market crashed on October, 24 1929. Investors from the Northeast United States either already took their money away from Florida, liquidating assents in favor of cash profits, or quickly moved out from real estate to cover their need for capital unfulfilled by a down-sloping stock market, leaving the locals, that were usually leveraged in their real estate, on negative equity positions. It would take years for the Florida real estate market to re-build its image (Nicholas \& Scherbina, 2012). Nerveless, after almost 200 years of development Florida land became a hot commodity looked after by developers and speculators. According to a statistics of the National Association of Realtors (NAR), quoted by Cummings (2006), in 2004 about $23 \%$ of Americans were purchasing real estate as a form of investment, and another $13 \%$ as second home. Florida would fall in line with these numbers. As Real Estate assumed a more prominent role in the state economy, the Florida Real Estate profession went from an unorganized, and selfdirected occupation heavily inspired by speculators, to a more formally organized profession.

Curtis (2005) described the processing of obtaining a Florida Real Estate license in great detail. In her article "Licensing and Discipline of Fiscal Professionals in the State of Florida: Attorneys, Certified Public Accountants, and Real Estate Professionals", Curtis compared and contrasted the Real Estate licensing process with other state regulated professions. In Florida Real Estate Brokers and Sales Associates act under chapter 475 part I of Florida Statute. Established in 1925 by the Florida legislature, the Florida Real Estate Commission (F.R.E.C.) is the political entity that oversees the practice of the profession. The commission is composed by seven members appointed by the Governor, and confirmed by the State Senate. Administrative services are provided by full time employees of the Division of Real Estate (D.R.E.) of the Florida Department of Business and Professional Regulation (D.B.P.R.).

There are two kinds of Real Estate licenses in Florida, either Broker or Sales Associate. To earn a Real 
Estate Sales Associate license, an aspirant must complete a pre-licensing class consisting of at least sixty fifty minutes hours, and pass an end of the course examination with a passing grade of $75 \%$ or better (now $70 \%$ or better). The end of the course examination is composed by 100 multiple choice questions (MCQ) having a stem and four possible options: three distractors and one correct answer. In addition to that, applicants must satisfy minimal educational requirements of having earned a high school diploma or its equivalent, must have a social security number to eventually allow the Florida Department of Revenues (Fl D.O.R.) to charge child support, and must be 18 years old or older. The term aspirant is an informal term that is not found in the Florida Statutes, but, for the purpose of the present study, it is used to qualify an individual that begins the process of getting licensed, before filing an application for licensure. Aspirants then, to become applicants, must also file an application through a centralized computer system or on paper, and pay a fee. After filing an application, the term used to qualify the individual becomes an applicant, and if the application is approved a qualified candidate. Qualified candidates though, still do not have a license, rather they must pass a 100 MCQ state exam with a score of $75 \%$ or better to finalize the licensing process and become licensee. Once passed the state exam for licensure, in fact, a license number gets originated associated with the successful candidate for licensure. The last administrative step to be fulfilled before beginning to practice is to activate that license number with a broker or a brokerage firm.

Bloggs (1992) and Smith (1949) describe in detail the activities of a Florida Real Estate Broker, and how Florida Real Estate licensees build their practice on the knowledge of the FREC I (F.R.E.C., 2015) Syllabus. Specifically, Bloggs (1992) addresses the law of Agency in Florida covered in Chapters 4 of the FREC I Syllabus, while Smith (1948) explains the legal theories of compensation for Florida Real Estate Brokers discussed in chapter 11 of the FREC I Syllabus. Remarkably, little or nothing has changed since then in terms of theoretical framework. Consequently, these chapters, together with chapter 5 (Real Estate Brokerage Operations) of the F.R.E.C. I (2015) Syllabus represent an important component of the state licensure test. As described in the 2018 Candidate Information Booklet (C.I.B.) these three chapters alone, represents about $31 \%$ of the state exam total number of questions.

Common traits of Real Estate professional nationwide are outlined by Benjamin and Sirmans (2000). These traits include basic demographics including level of education, gender, and earning expectations. While the numbers may have changed since then, the article by Benjamin and Sirmans portraits in detail the activities of Real Estate licensees. With respect of the statistics, the National Association of Realtors (N.A.R.), and the United States Census Bureau, provide reliable current estimates for most of the indicators. For example, if a Real Estate agent in the year 1990 earned a median income of \$41,489 (Benjamin and Sirmans, 2000), according to the 2017 US Census Bureau (United States Department of Labor, 2017) a Real Estate agent in 2017 earns a median income of $\$ 45,990$. In outlining the pros and cons of the Real Estate profession, Benjamin and Sirmans (2000) point out that the low barrier of formal education, the ability of making ones' own hours, and the potentially unlimited earning capacity are all factors contributing to the decision-making process of entering the profession.

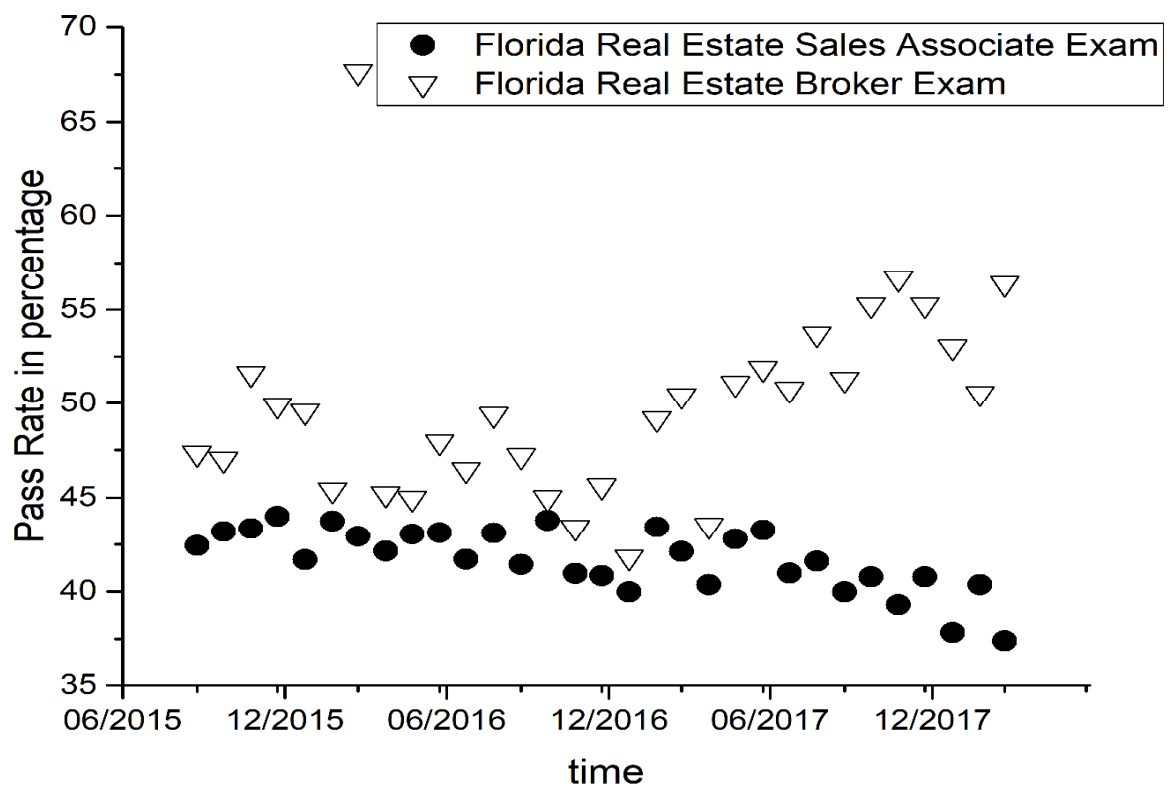

Figure 1. Florida Real Estate State licensure test performances expressed as a percentage of the total number of qualified candidates respectively for the Sales Associate and for the Broker exams for the fourth quarter 2015, for the entire year 2016, for the entire year 2017, and for the first quarter 2018 (B.E.T., 2017). 
Historically one of the challenges of real estate schools in Florida has been to increase the pass rate of their students at the state licensure exam (Brown-Climer, 2017; Lofton, 2017). The Florida Real Estate Sales Associate and Florida Real Estate Broker state exams are relatively challenging exams with low pass rates. If one looks at the success rate of aspirants for a Florida Real Estate license from the point of view of the school administrator, the scenario is less than perfect. According to the D.B.P.R., every month about three to five thousand qualified candidates take a Florida Real Estate or Real Estate Appraisal licensure test (D.B.P.R. Bureau of Education and Testing, 2017). Table 1 reports the Florida Real Estate State licensure test performances respectively for the Sales Associate and for the Broker exams for the fourth quarter 2015, for the entire year 2016, for the entire year 2017, and for the first quarter of the calendar year 2018. These data are provided by the test vendor, currently Pearson-Vue, and they are published as a matter of public records by the Florida D.B.P.R. The original sets of data provide separate information for first time test takers, and for repeaters, the data of Table 1 are the totals. For the Sales Associate state licensure test the mean pass rate averaged out over ten quarter is $42 \%$ associated to a standard deviation of $1.6 \%$. The median is also $42 \%$ while the mode is $40 \%$. The range for the monthly Sales Associate pass rate goes from a minimum of $37 \%$ to a maximum of $44 \%$ in the ten quarter under consideration.

Table 1. Florida Real Estate State licensure test data respectively for the Sales Associate and for the Broker exams for the fourth quarter 2015, for the entire year 2016, for the entire year 2017, and for the first quarter 2018 (B.E.T., 2017).

\begin{tabular}{|c|c|c|c|c|c|c|}
\hline Pass & $\begin{array}{c}\text { Florida } \\
\text { Sales } \\
\text { Fail }\end{array}$ & $\begin{array}{c}\text { Real } \\
\text { Associate } \\
\text { Total }\end{array}$ & Estate & $\begin{array}{c}\text { Exam } \\
\text { Pass }\end{array}$ & $\begin{array}{c}\text { Performance } \\
\text { Broker } \\
\text { Fail }\end{array}$ & Total \\
\hline \multicolumn{7}{|c|}{2015} \\
\hline 2,640 & 3,582 & 6,222 & Sep-15 & 231 & 257 & 488 \\
\hline 2,797 & 3,679 & 6,476 & Oct-15 & 221 & 249 & 470 \\
\hline 2,248 & 2,938 & 5,186 & Nov-15 & 259 & 243 & 502 \\
\hline 2,333 & 2,970 & 5,303 & $D e c-15$ & 232 & 233 & 465 \\
\hline 1,878 & 2,628 & 4,506 & Jan-16 & 165 & 168 & 333 \\
\hline 2,290 & 2,945 & 5,235 & Feb-16 & 158 & 190 & 348 \\
\hline 2,551 & 3,390 & 5,941 & Mar-16 & 209 & 190 & 309 \\
\hline 2,457 & 3,374 & 5,831 & Apr-16 & 188 & 228 & 416 \\
\hline 2,472 & 3,269 & 5,741 & May-16 & 183 & 224 & 407 \\
\hline 2,597 & 3,425 & 6,022 & Jun-16 & 209 & 227 & 436 \\
\hline 2,284 & 3,193 & 5,477 & Jul-16 & 158 & 182 & 340 \\
\hline 2,803 & 3,699 & 6,502 & Aug-16 & 239 & 245 & 484 \\
\hline 2,273 & 3,214 & 5,487 & Sep-16 & 210 & 235 & 445 \\
\hline 2,271 & 2,917 & 5,188 & Oct-16 & 197 & 241 & 438 \\
\hline 2,102 & 3,032 & 5,134 & Nov-16 & 211 & 275 & 486 \\
\hline 1,953 & 2,830 & 4,783 & Dec-16 & 208 & 248 & 456 \\
\hline 1,697 & 2,547 & 4,244 & Jan-17 & 138 & 192 & 330 \\
\hline 2,059 & 2,682 & 4,741 & Feb-17 & 178 & 184 & 362 \\
\hline 2,345 & 3,224 & 5,569 & Mar-17 & 251 & 247 & 498 \\
\hline 2,165 & 3,199 & 5,364 & Apr-17 & 171 & 222 & 393 \\
\hline 2,479 & 3,314 & 5,793 & May-17 & 241 & 231 & 472 \\
\hline 2,526 & 3,312 & 5,838 & Jun-17 & 208 & 193 & 401 \\
\hline 2,265 & 3,263 & 5,528 & Jul-17 & 205 & 199 & 404 \\
\hline 3,015 & 4,233 & 7,248 & Aug-17 & 268 & 231 & 499 \\
\hline 1,561 & 2,344 & 3,905 & Sep-17 & 159 & 151 & 310 \\
\hline 2,317 & 3,365 & 5,682 & Oct-17 & 237 & 192 & 429 \\
\hline 2,068 & 3,194 & 5,262 & Nov-17 & 247 & 189 & 436 \\
\hline 2,317 & 3,365 & 5,682 & Dec-17 & 237 & 192 & 429 \\
\hline 1,850 & 3,038 & 4,888 & Jan-18 & 185 & 164 & 349 \\
\hline 2,124 & 3,139 & 5,263 & Feb-18 & 188 & 184 & 372 \\
\hline 2,118 & 3,344 & 5,662 & Mar-18 & 256 & 198 & 454 \\
\hline
\end{tabular}

For the Real Estate Broker test the ten quarters average pass rate is $50 \%$ associated to a standard deviation of $5 \%$. The median is also $50 \%$ while the mode is $55 \%$. The range for the monthly Real Estate Broker pass rate goes from a minimum of $42 \%$ to a maximum of $68 \%$ in the ten quarter under consideration. Figure 1 is a pictorial representation of the data in Table 1 expressed as a percentage of the total number of applicants. In the 
ten quarters under consideration about $60 \%$ of the qualified candidates taking the state licensure test every month fail. The chart also shows that pass rates have been steadily lagging around $40 \%$, meaning that out of ten qualified applicants that stand the state test every month, four pass and six fail. In addition to these low pass rates, there are other paths which may lead to failure. The public record does not necessarily provide information on the ultimate fate of the qualified candidate, in the sense that they classify the data in two groups: first time takers and repeaters, but the record does not make clear whether the qualified candidates drop their attempts of getting licensed after a failure, or they keep trying and what is the success rate of these attempts. In other word a qualified candidate may just decide after a critical number of fails to quit trying. Another could have its application time lapse, before successfully passing the state licensure test. These occurrences, that are dropout channels for qualified candidates, are not accounted for. What it is public record, again, is the number of licensees, so the number of successful qualified candidates that passed the state licensure test.

While a plethora of web sites comment these low passing rates (Brown-Climer, 2017; Lofton, 2017) little or nothing has been investigated or described at the scholarly level. In fact, most of the published articles dealing with education and Florida Real Estate licensees are at least a decade or two old. Anderson and Webb (2000) review the educational requirement for Real Estate licensure, but they also point out that better education may provide added value to a firm. In their article, Anderson and Webb (2000) describe the Most Rapid Approach Model (M.R.A.M.) where an individual manages to earn its license and meet the minimum legal requirement to safely practice, while still having room to maximize the quality of the services offered to the public, and its earning potentials.

Similarly McHugh (2014) analyzing the 2013 NAR member profile, concludes that there is a correlation between REALTOR ${ }^{\circledR}$ education and earning potentials. Feeding on a NAR statistics, rather than on a state-run census, the study by McHugh is limited as it systematically disregards all the licensees working for commercial firms that do not join the respective local board of REALTORS, or the residential firms that do not join the board by choice. On the other hand, her study underlines the fact that the highest level of production, at least for the year 2013, was achieved by individuals with post-graduate education. Similar conclusions were obtained by a study performed by Hepp and Dawkins (2013) based on the 2010 N.A.R. REALTOR survey. Hepp and Dawkins (2013) found that REALTORs having at least an Associate degree earn 6\% average more than other having lower qualifications, REALTORs having at least a Bachelor degree earn at least $12 \%$ more than other having lower formal qualifications, and REALTORs having a graduate degree earn at least $23 \%$ more than others having lower qualifications.

If education, as it seems, is a predictor of an agent future earnings one would wonder why are the passing rates at the state test so low. In addition to that, another reason of concern comes from the fact that there are several more dropout channels in the path to Florida Real Estate licensure that are not addressed or accounted for. One of the goals of this article is to show that out of total population of Real Estate aspirants that make a formal move (literally spend some money) to earn a Real Estate license in Florida, there are several that never even get to become eligible applicant.

The purpose of this study is then to articulate and qualitative describe the possible different paths that may lead to failure for an aspirant. The significant of this study is critical for two reasons: it makes school administrators boldly aware of possible failure paths, it serves as the basis for further research designed to improve success rates by minimizing the impact of failure paths on students' lives. Florida real Estate School are entities licensed by the D.B.P.R. and may include proprietary schools, colleges, universities, and career centers. For a small proprietary school, establishing a good reputation improves substantially the chances of survival in a competitive market. One way to establish a good reputation is to maximize overall students' pass rate. 61J217.013(1), F.A.C. prohibits schools to guarantee that a pupil would pass the state exam, still school instructors and administrative personnel would want to maximize the practical chances for a students to succeed academically.

In the manufacturing sector today, human capital is still essential for most factories to carry out a variety of manual operations, in spite of the rapid advancement of automation technology and robotics. Futuristic vision of "unmanned manufacturing" (Deen 1993) is forbiddingly expensive, because all its hardware components need to be computer controlled so as to freely communicate with each other; and yet, most of the outcomes are not promising (Sun \& Venuvinod 2001). By and large, factories equipped with relatively simple machinery controls will require continuous attendance of human operators; for examples, textile mills, leather products, and medical appliances. With limited capital investments in production equipment, the main budget of their fixed costs lies on the workforce size (Techawiboonwong et al. 2006).

With regard to cost-effectiveness, labour planning always opts for the minimum amount of workers needed to deal with the daily operations, as well as the probable rate of disturbance (Lim et al. 2008). The workforce disturbance is often ascribed to absenteeism and turnover, which may result in considerable loss of productivity for any labour-intensive division (Easton \& Goodale 2002). Buffering with redundant skilled workers (Molleman \& Slomp 1999) or relief workers (Redding 2004) might be a direct solution to absenteeism; however, 
the rising labour cost must be justifiable due to the fact that underutilisation of labour during low demand seasons is considered a waste of resources. Absenteeism is the measure of unplanned absences from workplace due to some reasons like personal emergency, accident, illness, etc. Turnover occurs when an active worker resigns from the company of his own accord, thus leaving a vacant post until a replacement is found. If such disturbance has caused a large number of tasks become unattended and overdue, the company is then vulnerable to overtime cost, shrunk capacity and productivity, extra queuing time, lost business income, etc. In order to prevent these deteriorative effects, optimising the number of workers can be helpful. As a fundamental branch of knowledge in manufacturing business, workforce management will never fall behind the times. Therefore, it is worth an attempt to incorporate a novel methodology, such as HMS, into the state of the art of workforce sizing.

\section{Materials and Methods}

The main research question of the present paper is to articulate and describe which are the paths to failure for a Florida Real Estate licensure applicant. This is done by reviewing statutory information including:

- Florida Real Estate license law (F.S. 475),

- Florida general licensing provisions (F.S. 455),

- the rules of the Florida Real Estate Commission, the F.R.E.C. (61-J2 of the Florida Administrative Code), and

- the Candidate Information Booklet (C.I.B.) developed by the D.B.P.R.

The information extracted from these documents are triangulated with environmental observation that describe specific cases of failure. The preliminary observations articulated in this study will be used as a basis for developing educational support tools to minimize aspirants' failure rates. The present study is then designed to provide a better understanding to real estate instructors, students' counselors, and advisors on the main cause of real estate aspirants' dropout. If used properly the background information presented in this study will contribute to minimize loss of people's time, money and efforts, and maximize aspirants' success. By being aware of the most common causes of dropout from a real estate licensure path, a students' counselors formulate strategies together with the students to overcome them. To the best knowledge of the authors, no or little theory has been developed on this topic that being associated with a vocational trade, is often overlooked by other scholarly authors. On the other hand, universities, community colleges, proprietary schools, and career institutes may benefit from the outcomes of this analysis in terms of increased success rate.

The universe of Real Estate licensee aspirant is defined in this paper as the totality of the individuals that took at least one step toward earning a Florida Real Estate license. Data for this universe are largely unknown. The Florida D.B.P.R. only publishes the list of applicants, consisting of the people that filed an application, and the list of the licensees: the list of the people who actually earned a license. Students or pupils are aspirants actively enrolled in a Commission approved pre-licensing course. Applicants are aspirants that filed an application with the department (D.B.P.R.) and paid the application fee. Eligible candidates are applicants that successfully passed the application process and are ready to stand for the state licensure examination.

As stated above little or no information is available on the individual that, for example, spend $\$ 500$ to take a Real Estate pre-licensing class, but never file the application. No information is available is also available on the individual that, for example, spend $\$ 65$ to have its fingerprint taken for the purpose of Real Estate licensure, but never follow up with that by filing an application or taking the class. While the demographic of a person seeking licensure status in Florida are not of public domain, it is safe to assume that this population is largely characterized by individuals that meet the minimum legal qualifications. Overqualified individuals are also known to be part of that pool, but they represent a smaller group. According to the State of Florida Bureau of Education and Testing (B.E.T., 2017) about 60,000 qualified candidates every year attempt the Real Estate state licensure exam. The fee charged by the state appointed test vendor for the licensure test is currently $\$ 36.50$, generating revenue for the test vendor just shy of $\$ 2.2 \mathrm{M}$. This without taking into account the additional revenues associated with reviewing the tests, and eventually taking the fingerprints with the very same vendor. The same published statistics indicate that the pass rate for the state licensure test are at about $40 \%$ implying that at least $\$ 1.3 \mathrm{M}$ are spent by eligible candidate without a final tangible result. This $\$ 1.3 \mathrm{M}$ going to waste every year, adds to otherwise unaccounted expenses for pre-licensing education classes, fingerprints, and study material. \$36.5 may not seem much, but if one puts itself in the perspective of an aspirant earning $\$ 8.5 /$ hour, just a little bit above Florida $\$ 8.25$ /hour minimum wage, $\$ 36.5$ is more than half a day of work.

That \$36.5 lost taking a test, does not account for all the money spent and time invested into this undertaking. From the point of view of the aspirant, working in the majority of cases for just above minimum wage, it is critical to maximize its chances to earn its license. The schools, as educational institutions need, as a consequence, to understand that need and cater to it. The need for the present investigation therefore, span for the huge amount of money, time, and effort invested in the pursuit of real estate licensure in Florida, that ultimately go to waste. A survey of the prices of eleven different pre-license licensure courses offered either online or in a classroom setting for Florida Real Estate licensees, indicates a median price for the course of \$249. If one 
extends the reasoning above to the cost of education sustained by the students, the amount of money that does not produce a positive result every year is just short of $\$ 9 \mathrm{M}$.

Because of the large degree of uncertainty in this field a qualitative, almost descriptive approach is needed to shed light of the mechanisms involved in the licensure process. This is where the literature review, the background section, and the qualitative part of the investigation fit. As suggested by Pietkiewicz \& Smith (2014) this section is very pertinent because it helps to understand the psychological basis for the aspirants' decisions.

\section{Results and Discussion}

Document review is a qualitative way of investigation that is widely accepted in the research community. Generally speaking, document review finds applications in triangulations where it is combined with other research techniques to substantiate their findings. Bowen suggests that document review can serve five specific functions:

- Document can provide data about the environments in which research participants operate;

- Information contained in documents may generate questions that where not addressed, or not fully addressed in the document itself;

- Documents may provide supplementary research data;

- Documents may provide a way to historically track the development of an issue; and

- Data provided in documents may be used to corroborate other findings.

In 2017 Bretschneider et al. articulated the main characteristics of a qualitative research developed by document review in a matrix indicating both public records and government originated documents as possible significant form of information. In accordance with this idea, the present study provides a review of publicly available documents mainly generated by the State of Florida and presents them in a meaningful way to underscore and outline important aspirant dropout pathways to Real Estate schools' administrators and instructors. There are three different steps to become licensed in Florida as Real Estate Sales Associate, and they are outlined in a publication of the D.B.P.R. called the Candidate Information Booklet (C.I.B.). These three steps include passing a criminal background, filing an application, and taking and passing a pre-licensing course. Once an aspirant has successfully completed all these three steps it becomes a qualified candidate for the state licensure test. These three steps do not need to be taken in any specific order, although aspirants usually follow the path illustrated in Figure 2, where they begin their studies and become aware of the procedure for getting licensed during class. Figure 3 illustrate the possible paths leading to licensure, for an aspirant that begins the licensing process by filing an application. Figure 4 illustrate the case that is the least likely to happen, although is the one that would minimize the aspirant expenses, where the first step in the licensing process is to have its fingerprint taken and forwarded out for the criminal background.

Going back to Figure 3, as an exemplary case, the application can be accepted, if the candidate fulfills the statutory requirements of having a high school diploma, a social security number to be charged child support, and a high school diploma, or may be rejected if the applicant lacks any of the qualifications above. If the application becomes approved the applicant has then the choice to enroll in a pre-licensing class or to have its fingerprints done. The fingerprints are forwarded to the Federal Bureau of Investigation (F.B.I.) to perform a criminal background search. If the results of the search are negative, the application moves forward to the next step. If the results of the search are positive, the application is presented to F.R.E.C. with recommendations to deny the application, or to give further discussion to the application depending on the gravity of the violations. If the violations are serious, or if the applicant failed to disclose them in the application, denial is the more likely outcome. If the violations are old, and eventually not related to the profession, the Commission (F.R.E.C.) can request testimonies to ascertain the moral character of the applicant, and eventually consider the totality of the circumstances before making a final determination.

One would think that a student would be self-aware of its criminal background. In the fourth quarter 2015, a pre-licensing student consulted his instructor regarding the denial of his application based on a poor criminal record. The instructor suggested to contact the D.B.P.R. and request the list of the violations that prevented him to qualify for licensure. The D.B.P.R. customer service center returned a fax with several outstanding arrest warrants linked to Driving Under the Influence (D.U.I.) cases. The instructor questioned then the student asking if he was aware of the bench warrants, and the student candidly admitted that he was not aware of the warrants because he never appeared in court for any of the hearings. The instructor never fully understood if the student was sincere or not, but if one spends the tuition fee for the pre-licensing course it would be safe to assume that he was acting in good faith. For the purpose of the present paper though, the intention of that particular student, or his awareness of the criminal warrants are not important. What is important is the fact that at least one of such a case exists, where an aspirant only realizes of the lack of qualifications after filing the application and paying the fee for that, and after taking the pre-licensing class.

With regards to the pre-licensing class: it is a separate venture. Strict attendance rules allow students only to miss $10 \%$ of the credits hour. For example, a car accident, or a death in the family can seriously jeopardize the 
ability of a student to complete its pre-licensing course fulfilling the attendance requirements. The final exam is also regulated as the student is only allowed two attempts. The point in case, is that every step of the application process can lead to a myriad of reasons to fail and get dropped out. Just by counting the possible application pathways represented in Figure 3, only two paths, respectively numbered 5, and 6, lead to an approved candidacy, while there are five additional paths that lead the aspirant to drop $(1,2,3,4$, and 7$)$. The relative importance of these paths is unknown, and it would be impossible to provide a quantitative estimate of how many aspirants follow each path. One thing is sure: out of the aspirants that successfully reach the status of approved candidate only $40 \%$ become licensed. If one extends the reasoning around Figure 2, to Figures 3 and 4 it is possible to notice that there are a total of 6 paths leading to approved candidacy $(5,6,11,13,18$, and 19) and fifteen paths leading to drop $(1,2,3,4,7,8,9,10,12,14,16,17,19,20$, and 21). A school advisor should be well aware of this disparity and warn the student before enrolling in a class and pay the enrollment fee of the possible ways of being disqualified.

For a Florida Real Estate Licensee aspirant, the direct cost of licensing ran about $\$ 700$ including $\$ 100$ for the application, $\$ 65$ for the fingerprints, $\$ 36.5$ for the state test, and about $\$ 500$ for the pre-licensing course. While $\$ 800$ may not see a lot for a professional, they may become an unsurmountable obstacle for someone earning just a little more than minimum wage. The $\$ 36.50$ dollar amount spent on a failed state licensure test assumes more of a symbolic value, rather than being considered for its minimal face value. Therefore, it is critical for a real estate school, intended as an educational institution, to coach the aspirant to overcome academic and non-academic obstacles to the licensure goal. Ideally, a Florida Real Estate aspirant should have its fingerprints done first to minimize expenses, then verify its eligibility by filing the application, and finally taking the pre-licensing class. This would be the correct order to minimize possible monetary losses. The present paper is a preliminary step to the more ambitious goal of developing a tool to suppress or minimizing Academic and non-Academic failure contributing factors, and it points out that more research is needed as to identify what are the specific causes of aspirant dropout. While very minimal scholarly research has been done on this topic, a Mixed Method Research (M.M.R.) approach, where quantitative data are combined with qualitative explanations, may be the most effective way to resolve the (Mayo \& Onwegbuzie, 2014) questions that were left unanswered in this study.

\section{Conclusion}

The analysis of officially published documents triangulated with environmental observation presented in the present study underscores the existence of several channels or pathways, at least fifteen, leading to permanent dropout in the Florida Real Estate licensing process. Because of the relatively weak background that characterizes aspirants, students, applicants, and qualified candidates it is critical for schools' personnel to understand these pathways in order to minimize their potential impact on each individual. Despite the fact that the pass rates at the state licensure exam are not high, non-academic factors may have even a more significant impact on the ultimate fate of Florida Real Estate license aspirants', but because of the fragmentary information available to study this process, the relative importance of these non-academic factors may not necessarily be fully understood. Schools should be encouraged to implement tangible counseling programs to minimize the economic damage to students that pay for the classes but struggle to achieve their licensing goals. Future research efforts should focus on the sociological and human aspects affecting the dropout channels: if an aspirant makes an affirmative step toward earning a license, why its dropout should be considered normal? Why society does not put in place a support system to allow that aspirant to become a licensee. These are inquiries that cannot be addressed strictly at the academic level, but that also need a profound sociological and humanistic analysis. The need and the importance of additional study on this life changing process, becomes therefore more urgent and evident.

\section{References}

Anderson, R., \& Webb, J. The education of real estate salespeople and the value of the firm, Journal of Real Estate Research, 20(1-2), 2000.

Beckers, R., van der Voordt, T., \& Dewulf, G. Why do they study there? Diary research into students' learning space choices in higher education, Higher education research \& development, 35(1), 2016.

Benjamin, J., Jud, G., \& Sirmans, G. What do we know about real estate brokerage? Journal of Real Estate Research, 20(1-2), 2000.

Bloggs, H. G. Agency Law and Real Estate Brokerage, Business. LJ, 3, 1992.

Bowen, G. A. Document analysis as a qualitative research method, Qualitative research journal, 9(2), 2009.

Bretschneider, P.J., Cirilli, S. Jones, T., Lynch, S., Wilson, N.. Document review as a qualitative research data collection method for teacher research, Sage Publications Limited (2017).

Brocker, M., \& Hanes, C. The 1920s American Real Estate Boom and the Downturn of the Great Depression: Evidence from City Cross-Sections. In Housing and mortgage markets in historical perspective (pp. 161- 
201). University of Chicago Press, 2014.

Brown-Climer, A. The April and May 2017 Pearson Vue Real Estate Exam Pass Fail Performance Report in Real Estate, 2017.

Cumming Jr, J. B., \& Region, X. A Brief Florida Real Estate History, Appraisal Institute, 2006.

Curtis, D. M. Licensing and Discipline of Fiscal Professional in the State of Florida: Attorneys, Certified Public Accountants, and Real Estate Professionals, Nova Law Review, 29(2), 2005.

Fla. Admin. Code R. 61-J2 (2017).

Fla. Stat. $§ 455$ (2017)

Fla. Stat. $§ 475$ (ss. 475.001-475.5018) (2017).

Florida State Department of Business and Professional Regulations. Exam Performance Summary, 2017.

Florida State Department of Business and Professional Regulations. Candidate Information Booklet for the Real Estate Sales Associate Examination, 2018.

Florida Real Estate Commission. Sales Associate Course Syllabus, 2015.

Fuller, S.S. Economic Impacts of Commercial Real Estate, NAIOP Research Foundation, 2018.

Groenewald, T. A phenomenological research design illustrated. International journal of qualitative methods, 3(1), 2004.

Hepp, S.; Dawkins, C. Education and REALTOR ${ }^{\circledR}$ success? Journal of the Center for Real Estate Studies, 1(2), 2013.

Hill, H. Miami Beach Cityscape, n.d.

Lester, S. An introduction to phenomenological research, 1999.

Lofton, J. The Ugly truth about Florida Real Estate Schools and State Real Estate Testing Services, 2017.

Mayoh, J., Onwuegbuzie, A. J. Surveying the landscape of mixed methods phenomenological research, International Journal of Multiple Research Approaches, 8(1), 2014.

McHugh, T. Education and Success in Real Estate, Journal of the Center for Real Estate Studies 2(2), 2014.

National Association of REALTORS ®. Quick Real Estate Statistics, 2018.

Nicholas, T., \& Scherbina, A. Real estate prices during the roaring twenties and the great depression. Real Estate Economics, 41(2), 2013.

Parveen, Q., Yousuf, M. I., Mustafa, S. An experimental study on the effect of cooperative learning on students' academic achievement and students' perceptions towards cooperative learning, The Anthropologist, 27(1-3), 2017.

Pietkiewicz, I., \& Smith, J. A. A practical guide to using interpretative phenomenological analysis in qualitative research psychology, Psychological Journal, 20(1), 7-2014.

Saginor, J., Weinstein, M., \& Worzala, E. Graduate real estate education: a survey of programs after the great recession, Journal of Real Estate Practice and Education, 17(2), 2014.

Smith, H. B. The Florida Real Estate Broker and His Commissions, Miami LQ, 3, 424, 1948.

United States Department of Labour. Occupational Employment and Wages 41-9022 Real Estate Sales Agents, 2017.

Luca D'Ottone, (BS'97-MA'03-PhD'17) is an adjunct faculty with the School of Continuing Education and Professional Development of Miami Dade College. The author became licensed as Florida Real Estate Instructor in 2002, as a Florida General Real Estate Appraiser Instructor in 2005, and he become certified as an Appraisal Qualification Board (AQB) Uniform Standards of Professional Appraisal Practice (USPAP) instructor in 2009. The author's main interest is bringing novel and engaging teaching methods in the classroom. 


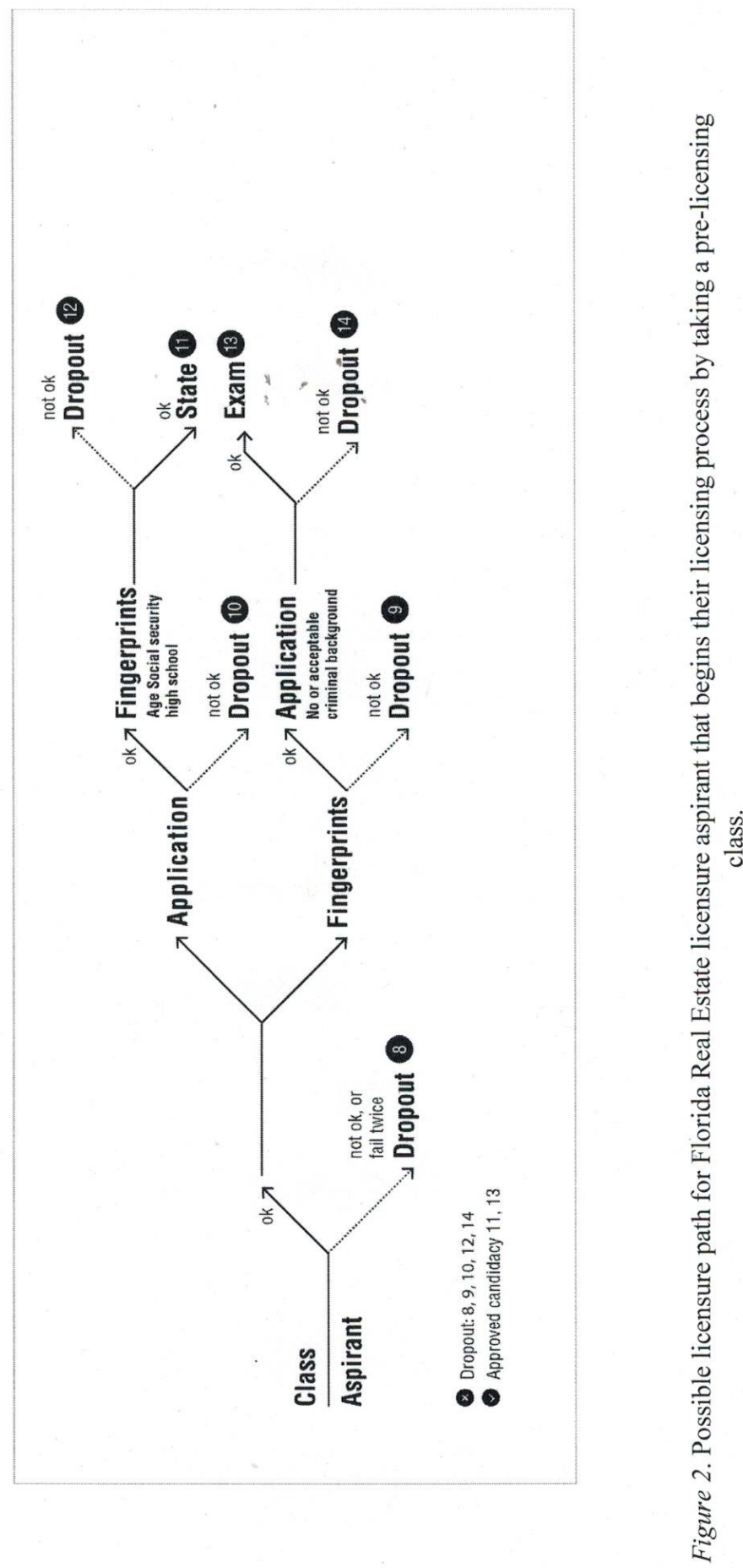




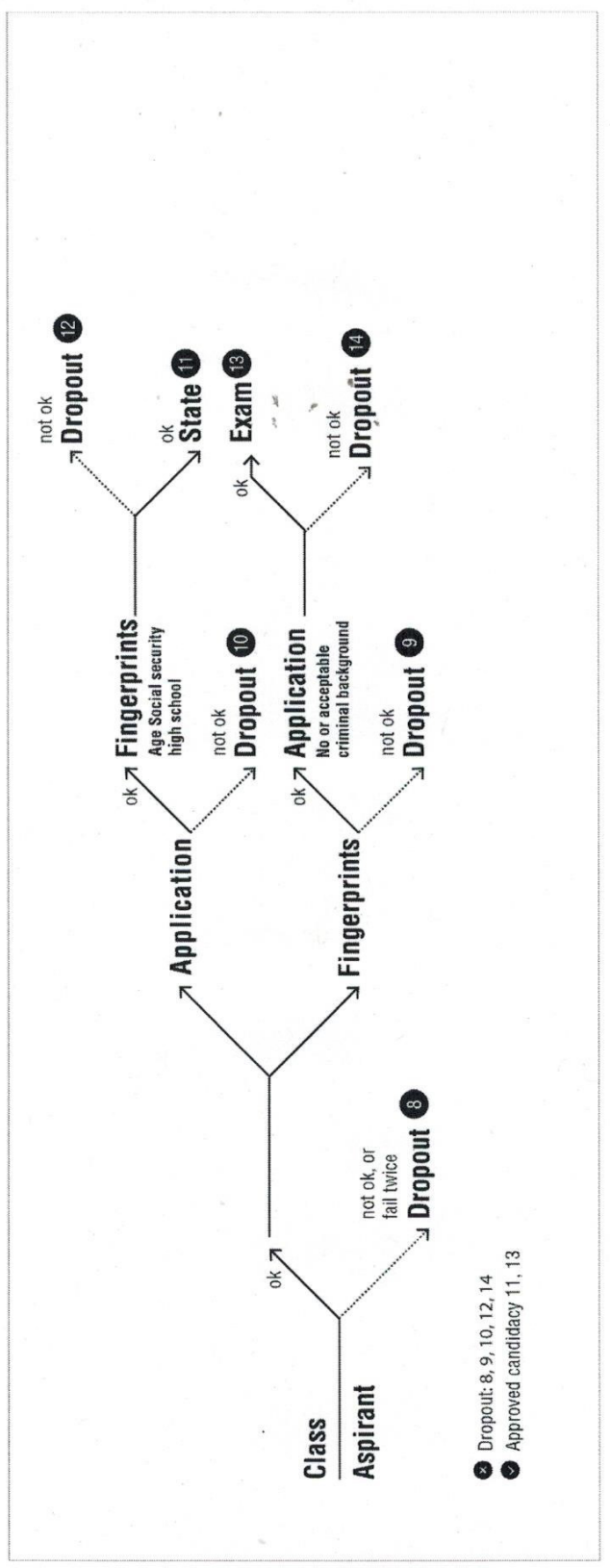


